\title{
担持貴金属水素化触媒を用いたシクロヘキサノールの 液相脱水素反応
}

\author{
（1989 年 9 月 25 日受理）
}

斉藤泰和・山下 勝* 一 一裕司

\section{1 緒 言}

シクロヘキサノールは酸化亜鉛または金属銅系触媒の存在下, $400 \sim 450^{\circ} \mathrm{C}, 1$ 気圧で加熱すると; シクロヘキサノンと水素を生 成する ${ }^{1)}$ 。一般に脱水素反応は分子数の増大する吸熱反応である から，平衡関係は低庄で反応温度が高いほど有利になる。

$$
\mathrm{C}_{6} \mathrm{H}_{12} \mathrm{O}(\mathrm{g}) \longrightarrow \mathrm{C}_{6} \mathrm{H}_{10} \mathrm{O}(\mathrm{g})+\mathrm{H}_{2}
$$

シクロヘキサノールの沸点 $\left(161^{\circ} \mathrm{C}\right)$ は, 式 (1) 飞示す脱水素 反応の標準 Gibbs 自由エネルギー変化が、゙口となる $\left(235^{\circ} \mathrm{C}\right)^{2)}$ よりも低く, 脱水素反応にとって不利な温度領域にある。しかし ながら，沸点で液相のシクロヘキサノールを反応させると，生成 する水素は不可逆的に除去されるため, 脱水素過程は進行可能と なる。水素化反応と共通する温度領域で, 十分大きな脱水素活珄 を示す触媒があるかどらかは興味深い検討課題である。微視的可 逆性の観点に立てば，水素化触媒は液相脱水素反応触媒のよい候 補と考えられるからである。実際, ニッケル水素化触媒は, Raney $=$ ケル3)，ホウ化ニッケル4) ガス中蒸発法調製微粒金属二 ッケル5゙のいずれについても，2-プロパノール液相脱水素活性が 見いだされている。

担持貴金属触媒はケトン水素化活性をもつことが知られてい る6うしかし，アルコール脱水素反応については知見がないので, 本研究では，種々の担持貴金属触媒にシクロヘキサノール脱水素 活性が現われるかどらかを加熱還流条件下で検討し，シクロへキ サノン水素化活性と対比しつつ, 液相脱水素触媒探索に関する指 針を得ようと試みた。

東京大学工学部工業化学科, 113 東京都文京区本郷

1）多羅間公雄監修, “反応别実用触媒”, 化学工業社刊(1970) p. 561; 川本和明, 日化, 80，681(1959).

2) D. R. Stull, E. F. Westrum, Jr. G.C. Sinke, "The Chemical Thermodynamics of Organic Compunds", John Wiley \& Sons New York (1969) p. 437.

3) F. Claes, J. C. Jungers, Bull. Soc. Chim. Fr., Ser. 5, 25, 1167(1963).

4) D. E. Mears, M. Boudart, AIChEJ., 12, 313 (1966).

5) M. Noda, S.Shinoda, Y.Saito, Bull. Chem. Soc. Jpn., 61, 961(1988).

6) E. Breitner, E. Roginski, P. N. Rylander, J. Org. Chem., 24, 1855(1959) ; L. M. Werbel, E. F. Elslager, W. M. Pearlman, J. Org. Chem., 29, 967(1964); Y. Takagi, Sci. Papers Inst. Phys. Chem. Res., 57, 105 (1963).

\section{2 実 験 方 法}

シクロヘキサノールの液相脱水素反応では，次のよらな手順で 行った。炭素またはアルミナ粉末担持金属 (Ru, Rh, Pd および $\mathrm{Pt}$ ) 触媒（エヌ・イー・ケムキャット社製，担持金属量 $5 \mathrm{wt} \%$, $\mathrm{Pt} /$ 炭素触媒のみ $10 \mathrm{wt} \%$ ) の所定量 $200 \mathrm{mg}$ (Pt/炭素触媒の場合 は $100 \mathrm{mg})$ を反応容器 $(300 \mathrm{ml}$, 三つロフラスコ)に取り, シク ロヘキサノール $100 \mathrm{ml}$ を加之窒素直換した後, 超音波分散処理 （室温，1 分間保持）により触媒を懸濁状態にした。この毷濁溶液 を油浴 $\left(180^{\circ} \mathrm{C}\right)$ 加熱で沸騰させ，還流（水冷）状態が安定した 後, 生成する気体をガスビュレット $(1000 \mathrm{ml})$ で容量追跡した。 一方, シクロヘキサノン水素化反応については, 同し触媒の所定 量 (50 mg あるいは Pt 触媒では $25 \mathrm{mg}$ ) とへキサン $20 \mathrm{ml}$ を反 応容器 $(100 \mathrm{~m} l$, 三つロフラスコ) に取り, 水素置換ののち触媒 を態濁状態にし，まず油浴 $\left(50^{\circ} \mathrm{C}\right)$ で約 17 時間加熱還元前処理 を施してから，愻濁溶液にシクロヘキサノン $1 \mathrm{ml}$ を添加し，水 素化反応 (反応温度 $49.1^{\circ} \mathrm{C}$ ) による水素消費量をガスビュレット $(250 \mathrm{ml})$ で容量追跡した。

液相および気相生成物の組成分析は，ガスクロマトグラフィー （液相：PEG $20 \mathrm{M}$ ，気相：活性炭）によった。

\section{3 結 果}

3.1 炭素担持貴金属触媒によるシクロヘキサノール眖水素反 応

炭素担持貴金属触媒はいずれも良好な懸濁分散性を示した。シ クロヘキサノール液相脱水素反応の経時変化を図 1 に示す。炭素 担持パラジゥムお゙よび白金触媒では気相生成物は水素のみ, 口ジ ウム触媒では, 水素のほかに反応開始 1 時間後から極く少量の タンが気相中に検出された。ルテニウム触媒の場合は, トレース 量の水素が検出されるにとどまった。液相生成物はシクロへキサ ノンのみが得られた。貴金属種重量あたりの脱水素活性は, Pd> $\mathrm{Rh} \sim \mathrm{Pt} \gg \mathrm{Ru}$ の順序であった。

3.2 アルミナ担持黄金属触媒によるシクロへキサノール眖水 素反応

アルミナ担持貴金属触媒は㲘濁分散性に乏しく，超音波分散 処理してもすぐに沈降した。貴金属重量あたりの脱水素活性は $\mathrm{Rh}>\mathrm{Pd} \sim \mathrm{Pt} \gg \mathrm{Ru}$ の順となった。生成物は水素とシクロへキ廿 ノンのみであったが，活性は炭素担持触媒にくらべてかなり低か った（図 2 )。なお，アルミナ担持口ジゥム触媒の場合には，反応 開始直後より極く微量のメタンが検出された。 


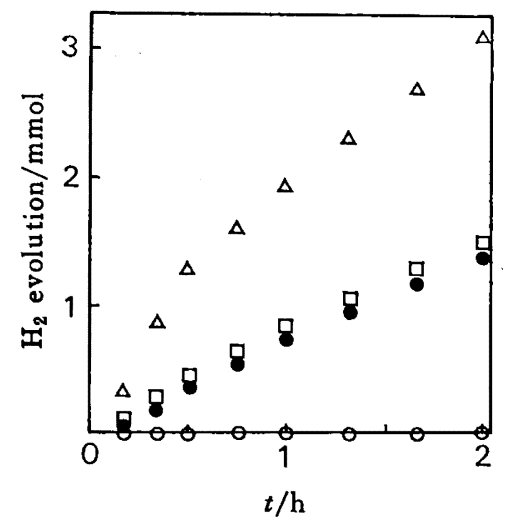

Fig. 1 Time-course plot of cyclohexanol dehydrogenation using carbon-supported noble metal catalysts under refluxing conditions $\left(161^{\circ} \mathrm{C}\right)$

Reactant : Cyclohexanol $(100 \mathrm{~m} l)$

Catalyst : Carbon-supported noble metal (10 mg); $\operatorname{Pd}(\triangle), \operatorname{Rh}(\square), \operatorname{Ru}(O)$, and $\operatorname{Pt}(\mathrm{O})$

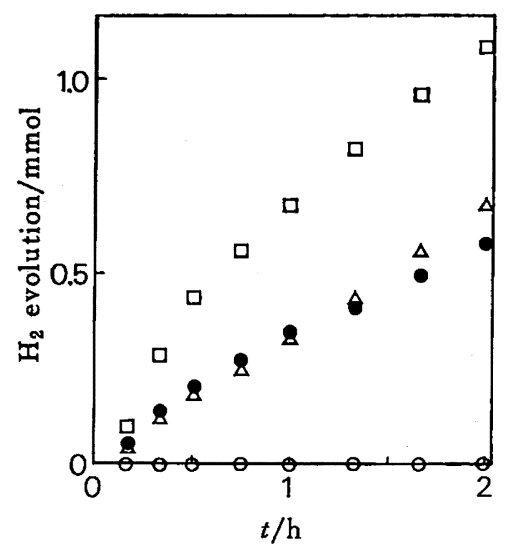

Fig. 2 Time-course plot of cyclohexanol dehydrogenation using alumina-supported noble metal catalysts under refluxing conditions $\left(161^{\circ} \mathrm{C}\right)$

Reactant : Cyclohexanol $(100 \mathrm{~m} l)$

Catalyst : Alumina-supported noble metal $(10 \mathrm{mg})$; $\operatorname{Pd}(\triangle), \operatorname{Rh}(\square), \operatorname{Ru}(O)$, and $\operatorname{Pt}(O)$

\section{3 担持貫金属触媒によるシクロヘキサノン水素化反応}

炭素担持金属触媒はへキサン中でも良好な懸濁分散性を示し，

貴金属重量あたりの水素化活性は， $\mathrm{Pt}>\mathrm{Rh}>\mathrm{Ru}>\mathrm{Pd}$ の順とな った（因 3)。一方，フルミナ担持貴金属触媒は㲘濁分散性に乏し く，還元前処理の段階ですでに沈降した。活性序列は $\mathrm{Pt} \gg \mathrm{Rh} \sim$ $\mathrm{Ru}=\mathrm{Pd}$ の順となった（図 4)。

\section{4 考察}

反応初期 (10 分後) と 2 時間後における液相脱水素-水素化反 応速度を表 1 と 2 亿をとめた。炭素担持パラジウム触媒は, シク ロヘキサノール液相脱水素活性が最も高く，乙かも優れた棌濁分 散性を示した。それに次く脱水素活性を示すロシシウム触媒は, 反 応初期には担体による差がみられないけれども，2時間後の活性 はよく分散する炭素担体の方か櫌れていた。白金触桇は初期速度

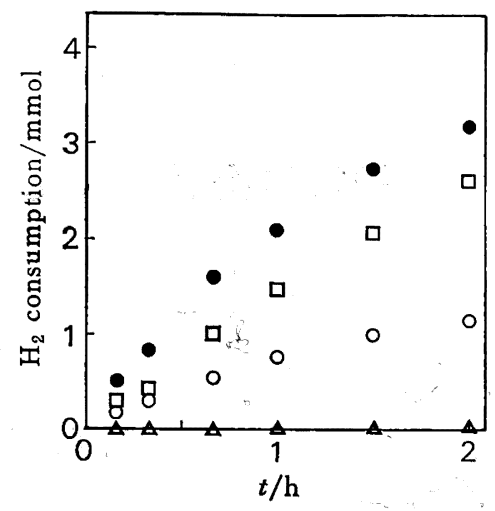

Fig. 3 Time course plot of cyclohexanone hydrogenation using carbon-supported noble metal catalysts at $49.1^{\circ} \mathrm{C}$

Reactant: Cyclohexanone $(1 \mathrm{ml})$, Hexane $(20 \mathrm{~m} l)$

Catalyst : Carbon-supported noble metal $(2.5 \mathrm{mg})$; $\operatorname{Pd}(\triangle), \operatorname{Rh}(\square), \operatorname{Ru}(O)$, and $\operatorname{Pt}(\mathrm{O})$

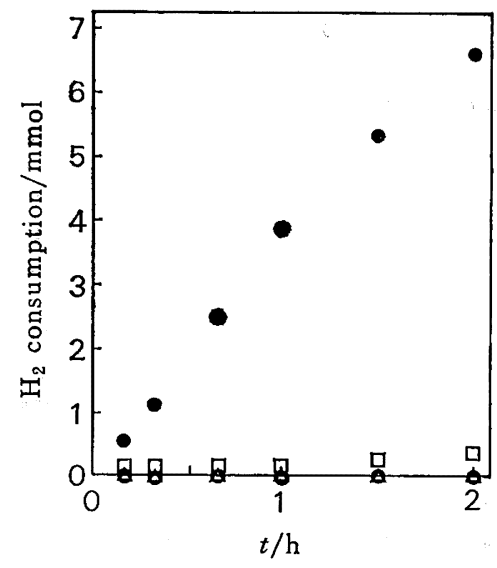

Fig. 4 Time-course plot of cyclohexanone hydrogenation using alumina-supported noble metal catalysts at $49.1^{\circ} \mathrm{C}$

Reactant: Cyclohexanone $(1 \mathrm{ml})$, Hexane $(20 \mathrm{~m} l)$ Catalyst : Alumina-supported noble metal $(2.5 \mathrm{mg})$; $\operatorname{Pd}(\triangle), \quad \operatorname{Rh}(\square), \quad R u(O)$, and $\operatorname{Pt}(O)$

Table 1 Reaction rates of cyclohexanol dehydrogenation using supported noble metal catalysts under refluxing conditions $\left(161^{\circ} \mathrm{C}\right)$

\begin{tabular}{|c|c|c|c|c|}
\hline \multirow{2}{*}{ Support } & \multicolumn{4}{|c|}{ Metal } \\
\hline & $\mathrm{Pd}$ & $\mathrm{Rh}$ & $\mathrm{Pt}$ & $\mathrm{Ru}$ \\
\hline \multirow{2}{*}{ Carbon } & 369.0 & 123.0 & 36.9 & 0 \\
\hline & 110.0 & 61.1 & 30.8 & 0 \\
\hline \multirow{2}{*}{ Alumina } & 49. 3 & 123.0 & 61.6 & 0 \\
\hline & 36.9 & 36.9 & 24.6 & 0 \\
\hline
\end{tabular}

Unit of reaction rate $: \mathrm{mmol} / \mathrm{h}$ (g-metal).

Upper row: Rate at $10 \mathrm{~min}$ after the reaction started. Lower row : Rate at $2 \mathrm{~h}$ after the reaction started. 
Table 2 Reaction rates of cyclohexanone hydrogenation using supported noble metal catalysts at 49. $1^{\circ} \mathrm{C}$

\begin{tabular}{|c|c|c|c|c|}
\hline \multirow{2}{*}{ Support } & \multicolumn{4}{|c|}{ Metal } \\
\hline & $\mathrm{Pt}$ & $\mathrm{Rh}$ & $\mathrm{Ru}$ & $\mathrm{Pd}$ \\
\hline \multirow{2}{*}{ Carbon } & 1177 & 724.6 & 452.9 & 0 \\
\hline & 724.6 & 422.7 & 120.8 & 0 \\
\hline \multirow{2}{*}{ Alumina } & 1359 & 271.7 & 0 & 0 \\
\hline & 1057 & 60.4 & 0 & 0 \\
\hline
\end{tabular}

Unit of reaction rate: $\mathrm{mmol} / \mathrm{h}$ (g-metal).

Upper row : Rate at 10 min after the reaction started.

Lower row: Rate at $2 \mathrm{~h}$ after the reaction started.

ではフルミナ担体の方が大きいものの, 速度低下の度合は炭素担 体の方が小さかった。触媒の懸濁分散性は, 固-液相不均一系にお

ける反応速度を維持する上で, 重要な要因の一つである゙。

シクロヘキサノン水素化反応は白金触媒が最も高い活性を示
し、ロジウム触媒がそれに次いた゚。またロジウムおよびルテニウ ム触媒についてみれば, 懸濁分散性のよい炭素担体の方がフル ナ担体より高い活性を与えた。しかし，フルミナ担持白金触媒の 場合はアルミナ担体の方が高い活性であることからわかるよう に，反応速度の大きさを㲘濁分散性のみに㷌するわけにはいかな い。

シクロヘキサノール脱水素活性を持つパラジゥム触媒にシクロ ヘキサノン水素化活性がなく, シクロヘキサノール脱水素化活性 を示さないルテニウム触媒にはシクロへキサノン水素化活性が認 められる。水素化触媒への基質ヶトンと水素の吸着は, 脱水素反 応にとっては生成物の脱離に相当する。他の基質を含めた水素化 活性の知見は，そのような排反的な要因を考虑に入れつつ優れた 脱水素触媒の開発に生かすことができると思われる。

7）山下 勝，小島 弘，鈴木 賏，斉藤泰和，日化， 1988， 1292.

\title{
Liquid-Phase Dehydrogenation of Cyclohexanol with Supported Noble Metal Hydrogenation Catalysts
}

\author{
Yasukazu Sarto, Masaru Yamashita* and Yuji Ichinohe \\ Department of Industrial Chemistry, Faculty of Engineering, The University of Tokyo ; \\ Hongo, Bunkyo-ku, Tokyo 113 Japan
}

Cyclohexanol dehydrogenation and cyclohexanone hydrogenation were performed with suspended noble metal catalysts. The orders of initial dehydrogenation rates, $\mathrm{Pd}>\mathrm{Rh} \sim \mathrm{Pt} \gg \mathrm{Ru}$ and $\mathrm{Rh}>\mathrm{Pd} \sim \mathrm{Pt} \gg \mathrm{Ru}$ obtained for the catalysts supported on carbon and alumina respectively, were different from those of hydrogenation.

In cyclohexanol the suspended states of carbon-supported catalysts were stable, with the dehydrogenation activity retained for a long period. The platinum catalysts were the most active for hydrogenation. Contrast between the palladium and ruthenium catalysts observed in the behaviors of dehydrogenation and hydrogenation is particularly interesting for developing good liquid-phase dehydrogenation catalysts. 